\title{
Pengaruh Investasi Pertambangan dan Tenaga Kerja terhadap Produk Domestik Regional Bruto serta Indeks Pembangunan Manusia di Kabupaten Kutai Barat
}

\author{
Yakin Masiku$^{1}$, Adi Wijaya ${ }^{2}$, Eny Rochaida ${ }^{3}$ \\ Magister Ilmu Ekonomi Fakultas Ekonomi dan Bisnis Universitas Mulawarman, Indonesia \\ Email:
}

\begin{abstract}
Abstrak
Tujuan dari penelitian ini adalah untuk menguji Pengaruh Investasi dan Tenaga Kerja terhadap Produk Domestik Regional Bruto serta Indeks Pembangunan Manusia di Kabupaten Kutai Barat. Data yang digunakan data sekunder yang bersumber dari Dinas Pertambangan Kabupaten Kutai Barat dan Kantor Biro Pusat Statistik Kabupaten Kutai Barat, Bappeda Kabupaten Kutai Barat dan Dinas terkait. Adapun metode pungumpulan data dengan pengamatan langsung. Selanjutnya data diolah dan dianalisis dengan Analisis Jalur (Path Analysis). Hasil uji statistik menunjukkan bahwa secara parsial Investasi Pertambangan berpengaruh positif namun tidak signifikan terhadap PDRB serta IPM, sedangkan Jumlah Tenaga Kerja berpengaruh positif dan signifikan terhadap peningkatan penerimaan PDRB di Kabupaten Kutai Barat. Sedangkan PDRB berpengaruh positif dan signifikan terhadap IPM di Kabupaten Kutai Barat.
\end{abstract}

Kata Kunci: Indeks Pembangunan Manusia

\section{Effect of Mining Investment and Labor to Regional Bruto Domestic Product And Human Development Index in District Kutai Barat}

\begin{abstract}
The purpose of this study was to examine the influence of investment and labor on Gross Regional Domestic Product and Human Development Index in West Kutai District. Data used secondary data sourced from the Mining Service of West Kutai Regency and Central Bureau of Statistics Office of West Kutai Regency, Bappeda of West Kutai Regency and related Office.The method of data collection with direct observation. Further data is processed and analyzed by Path Analysis (Path Analysis). The result of statistical test shows that partially Mining Investment has positive but not significant effect to PDRB and HDI, whereas the amount of Labor has positive and significant effect to the increasing of PDRB revenue in West Kutai Regency. While PDRB has a positive and significant impact on HDI in West Kutai Regency.
\end{abstract}

Keywords: Human Development Index 


\section{PENDAHULUAN}

\section{Latar Belakang}

Pengukuran keberhasilan pembangunan telah berkembang dari waktu ke waktu. Tahun 1990 Perserikatan Bangsa Bangsa mulai memperkenalkan ukuran keberhasilan pembangungan melalui suatu indeks yang disebut Indeks Pembangunan Manusia (IPM). IPM merupakan suatu ukuran yang meliputi gabungan tiga dimensi tentang pembangunan manusia, yaitu(1) usia panjang yang diukur dari usia harapan hidup, (2) pengetahuan yang diukur dengan rata-rata tertimbang dari jumlah orang dewasa yang dapat membaca dan rata-rata tahun sekolah, dan (3) penghasilan yang diukur dengan pendapatan per kapita riil yang telah disesuaikan menurut daya beli mata uang masing-masing negara (Kuncoro, 2006).

Mengutip isi Human Development Report (HDR) pertama tahun 1990, pembangunan manusia adalah suatu proses untuk memperbanyak pilihan-pilihan yang dimiliki oleh manusia. Diantara banyak pilihan tersebut, pilihan yang terpenting adalah untuk berumur panjang dan sehat, untuk berilmu pengetahuan, dan untuk mempunyai akses terhadap sumber daya yang dibutuhkan agar dapat hidup secara layak.

Indeks Pembangunan Manusia (IPM) mengukur capaian pembangunan manusia berbasis sejumlah komponen dasar kualitas hidup. Sebagai ukuran kualitas hidup, IPM dibangun melalui pendekatan tiga dimensi dasar. Dimensi tersebut mencakup umur panjang dan sehat; pengetahuan, dan kehidupan yang layak. Ketiga dimensi tersebut memiliki pengertian sangat luas karena terkait banyak faktor. Untuk mengukur dimensi kesehatan, digunakan angka harapan hidup waktu lahir. Selanjutnya untuk mengukur dimensi pengetahuan digunakan gabungan indikator angka melek huruf dan rata-rata lama sekolah. Adapun untuk mengukur dimensi hidup layak digunakan indikator kemampuan daya beli masyarakat terhadap sejumlah kebutuhan pokok yang dilihat dari rata-rata besarnya pengeluaran per kapita sebagai pendekatan pendapatan yang mewakil i capaian pembangunan untuk hidup layak.

Investasi dan tenaga kerja sebagai penggerak ekonomi, yang pencapain akhirnya adalah peningkatan kesejahteraan masyarakat dan upaya perluasan berbagai pilihan kehidupan bagi penduduk yang diproksi melalui besaran IPM. Keberadaan IPM sebagai pembangunan kemampuan manusia melalui perbaikan taraf kesehatan, pengetahuan, keterampilan, dan pemanfaatan dari kemampuan/ keterampilan.

Berbeda dengan konsep pembangunan ekonomi yang menitik beratkan pada pertumbuhan, kebutuhan dasar, kesejahteraan masyarakat, dan pengembangan sumber daya manusia. Sementara pembangunan manusia menitik beratkan pada produktivitas, pemerataan, kesinambungan, dan pemberdayaan.

Untuk itu perlu potret kinerja pembangunan manusia Kutai Barat pada saat yang berbeda melalui studi Indeks Pembangunan Manusia (IPM) dengan indikator angka harapan hidup, angka melek huruf, lama bersekolah, dan ukuran pendapatan yang sudah disesuaikan dengan paritas daya beli. Indikator pertama mengukur "umur panjang dan sehat", dua indikator selanjutnya mengukur "pengetahuan dan keterampilan.

Pembangunan ekonomi sebagai suatu proses yang menyebabkan pendapatan perkapita penduduk suatu masyarakat meningkat dalam jangka panjang (Sukirno, 1985:25). Dari definisi pembangunan di atas terdapat tiga sifat pembangunan ekonomi yaitu : (i) suatu proses, yang merupakan perubahan yang terjadi terus menerus; (ii) usaha untuk menaikkan tingkat pendapatan perkapita; dan (iii) kenaikan pendapatan perkapita itu harus terus berlangsung dalam jangka panjang.

Berdasarkan pendapat tersebut di atas, maka penulis berpendapat bahwa proses pertumbuhan ekonomi tidak berjalan dengan stagnan dan terus mengalami fenomena- fenomena perubahan yang dapat di tinjau secara matematis. Pelaksanaan pembangunan nasional diarahkan pada aspek pemerataan pembangunan dan hasil-hasilnya; pertumbuhan ekonomi yang cukup tinggi; dan stabilitas nasional (Mustopadidjaja, 1997:12). Ketiga aspek tersebut saling terkait dan harus dikembangkan secara selaras dan terpadu. Hasil pembangunan yang dicapai melalui pertumbuhan ekonomi tersebut harus disertai 
Pengaruh Investasi Pertambangan dan Tenaga Kerja; Yakin Masiku

dengan pemerataan di seluruh masyarakat. Konsep pemikiran Mustopadidjaja ditujukan agar pembangunan dapat dilaksanakan secara adil dan merata oleh semua lapisan masyarakat.

Dari penjelasan tentang aspek stabilitas nasional dan pertumbuhan ekonomi diatas, penulis berpendapat bahwa pertumbuhan ekonomi mutlak didukung oleh terciptanya stabilitas nasional yang mantap.

Pertumbuhan ekonomi merupakan hasil nyata dari pembangunan yang dilaksanakan. Oleh karena itu tolok ukur adanya pembangunan ekonomi tersebut adalah terjadinya pertumbuhan ekonomi. Pertumbuhan ekonomi merupakan perubahan positif dari tingkat kegiatan ekonomi yang berlaku dari tahun ke tahun. Pertumbuhan ekonomi merupakan salah satu indikator yang amat penting dalam melakukan analisis tentang pembangunan ekonomi yang terjadi pada suatu negara atau wilayah, karena pertumbuhan ekonomi dapat memberikan gambaran sejauh mana aktivitas perekonomian akan menghasilkan tambahan pendapatan masyarakat pada suatu periode tertentu.

Peningkatan pendapatan nasional melalui peningkatan Produk Domestik Bruto (PDB) dan Produk Domestik Regional Bruto (PDRB) merupakan gambaran dari pertumbuhan ekonomi secara makro, variabel ini juga memberikan dorongan terhadap peningkatan daya beli masyarakat. Peran Ekonomi swasta dalam pembangunan dan pertumbuhan ekonomi Indonesia melalui kegiatan investasi asing dan dalam negeri.

Dalam mewujudkan pertumbuhan ekonomi di daerah, diperlukan investasi baik dari dalam daerah maupun dari luar daerah. Sehubungan dengan itu, dalam mencapai pertumbuhan ekonomi yang diikuti dengan peningkatan pendapatan perkapita ditetapkan berbagai kebijakan yang terutama pengembangan sumber-sumber pembiayaan pembangunan daerah harus ditingkatkan dan pada akhirnya menjadi sumber investasi daerah yang secara langsung maupun tidak langsung meningkatkan pendapatan dan kesejahteraan masyarakat.

Dalam praktek pembangunan di banyak negara, setidaknya pada tahap awal pembangunan, umumnya berfokus pada peningkatan produksi. Meskipun banyak varian pemikiran, pada dasarnya kunci dalam pembangunan adalah pembentukan modal melalui investasi. Oleh karena itu pembangunan yang dianggap paling sesuai adalah akselerasi pertumbuhan ekonomi dengan mengundang modal asing dan melakukan industrialiasi.

Peranan Tenaga kerja sebagai salah satu faktor produkis dalam strategi semacam ini hanyalah sebagai instrumen atau salah satu faktor produksi saja. Manusia ditempatkan sebagai posisi instrumen dan bukan merupakan subyek dari pembangunan. Titik berat pada nilia produksi dan produktivitas telah mereduksi manusia sebagai penghamba maksimisasi kepuasan maupun maksimisasi keuntungan.

Konsekuensinya, keberadaan tenaga kerja diarahkan dalam rangka peningkatan produksi. Inilah yang disebut pengembangan SDM dalam menopang peningkatan pertumbuhan ekonomi di dalam kerangka production centered development. Bisa dipahami apabila topik pembicaraan dalam persefektif paradigma pembangunan yang semacam itu terbatas pada masalah pendidikan, peningkatan ketrampilan, kesehatan, dan sebagainya yang pada akhirnya membutuhkan tenaga kerja yang produktiv dalam upaya mendorong pertumbuhan ekonomi.

Alternatif lain dari strategi pembangunan manusia adalah apa yang disebut sebagai peoplecentered development, yang berarti manusia merupakan tujuan utama dari pembangunan dan kehendak serta kapasitas manusia merupakan sumber daya yang paling penting. Dimensi pembangunan yang semacam ini jelas lebih luas daripada membentuk manusia profesional dan trampil sehingga bermanfaat dalam proses produksi, akan tetapi menempatkan manusia sebagai subyek pembangunan yang menekankan pada pentingnya pemberdayaan manusia yaitu kemampuan manusia untuk mengaktualisasikan segala potensinya. Gambaran umum Laju pertumbuhan ekonomi Kabupaten Kutai Barat berdasarkan PDRB harga konstan untuk tahun 2008 s/d 2009 terus mengalami peningkatan yakni tahun 2008 sebesar 6.83 persen, 2009 sebesar 6.89 persen, kemudian tahun 2010 mengalami penurunan yang cukup signifikan yakni hanya sebesar 5.53 persen, kemudian mengalami peningkatan yang signifikan kembali pada tahun 2011 yakni menjadi 8.05 persen, kemudian tahun 2012 mengalami penurunan kembali menjadi 7.15 persen dan tahun 2013 menurun kembali yakni hanya sebesar 5,73 persen hal ini disebabkan 
oleh naiknya inflasi sehingga menurunnya daya beli masyarakat rendah yang ditopang juga oleh merosotnya usaha masyarakat khususnya sektor kehutanan dan imbas menurunnya nilai jual karet dan batu batu bara.

Sampai dengan tahun 2014 ini peran Investasi swasta masih memberikan peran yang cukup besar dalam penggerak pertumbuhan ekonomi di Kabupaten Kutai Barat, tercatat sampai dengan tahun 2014 peningkatan pertumbuhan Penanaman Modal Dalam Negeri ( PMDN ) mencapai 1,79 persen. Peningkatan Investasi Pemerintah dalam pertumbuhan ekonomi dapat dilihat dari kenaikan jumlah Belanja Publik pada Anggaran Pendapatan dan Belanja Daerah.

Investasi yang sedang berkembang saat ini di Kutai Barat adalah bidang pertambangan dan perkebunan khususnya kelapa sawit. Perkembangan perkebunan sawit semakin digalakkan khususnya di wilayah Dataran Tinggi, seperti Kecamatan: Damai, Bongan, Jempang, Siluq Ngurai, Nyuatan. Namun dalam penelitian ini hanya difokuskan pada Investasi sektor pertambangan di Kabupaten Kutai Barat.

Adapun sektor dengan Tenaga kerja produktif tertinggi sebagai faktor produksi pada sektor tradisional yang meliputi : Sektor S (service) yaitu sektor perdagangan, perhubungan, keuangan dan jasa, sektor ini pada tahun 2014 sebanyak 50,51\% dari total pekerja, sektor A (agriculture) terbanyak kedua yakni sebanyak 34,03\% dari total pekerja, sektor modern, yaitu sektor M (Manufacture) yang terdiri atas sektor bangunan, sebanyak 23,36 \% dari seluruh pekerja yang ada di Kutai Barat.

Sumber Data Distamben dan BPS Kutai Barat (diolah)

Kutai Barat sendiri merupakan salah satu daerah yang PDRBnya sebagian besar ditopang oleh sektor pertambangan sebagaimana tahun 2014 PDRB yakni sebesar 53,15\%. Dengan sumbangsi yang besar ini menjadi pertanyaan apakah juga sudah berdampak besar bagi Pertumbuhan Kualitas Hidup Masyarakat (IPM) Kutai Barat khususnya jika dikaitkan dengan Investasi Pertambangan yang telah diinvestasikan dan Tenaga Kerja yang digunakan sampai saat ini melalui PDRB yang telah dihasilkan.

Berdasarkan uraian permasalahan tersebut maka peneliti tertarik untuk melakukan penelitian dengan judul: "Pengaruh Investasi Sektor Pertambangan dan Tenaga Kerja Terhadap Produk Domestik Regional Bruto serta Indeks Pembangunan Manusia di Kabupaten Kutai Barat”.

\section{METODE PENELITIAN}

\section{Definisi Operasional}

Defenisi operasional jelas tentang variabel-variabel yang akan dianalisis, maka berikut ini akan dijelaskan dalam definisi operasional:

1. Investasi Pertambangan (X1), Dalam penelitian ini investasi pertambangan yang dimaksudkan adalah investasi di sektor pertambangan Batu Bara di Kabupaten Kutai Barat Tahun 2006 - 2015 dengan satuan Rupiah

2. Tenaga Kerja (X2) adalah faktor produksi yang merupakan input untuk meningkatkan produktivitas. Tenaga Kerja dalam penelitian ini hanya dibatasi pada tenaga kerja sektor pertambangan di Kabupaten Kutai Barat Tahun 2006 - 2015 dengan satuan orang.

3. PDRB (Y1) adalah Data PDRB ADHK Kabupaten Kutai Barat tahun 2006 - 2015 dengan satuan juta rupiah

4. Indeks Pembangunan Manusia (Y2) adalah Indeks Perluasan pilihan bagi penduduk sekaligus sebagai taraf yang dicapai dari upaya tersebut, dengan indikator Pendidikan, kesehatan dan daya beli, indeks ini dihitung oleh BPS

Kabupaten Kutai Barat. Data IPM yang dianalisis dalam penelitian ini menggunakan data IPM Kabupaten Kutai Barat Tahun 2006 -2015 dalam satuan persentase (\%)

\section{Jangkauan Penelitian}

1. Penelitian dilaksanakan di Kabupaten Kutai Barat Propinsi Kalimantan Timur

2. Data yang digunakan adalah data sekunder Time Series (Runtut Waktu) selama periode 2004 - 2015. 


\section{Rincian Data yang Diperlukan}

Data yang diperlukan dalam penelitian ini antara lain:

1) Gambaran Umum Kabupaten Kutai Barat.

2) Data Produk Domestik Regional Bruto (PDRB ADHK) Kabupaten Kutai Barat tahun 2006 hingga tahun 2015.

3) Data Investasi Sektor Pertambangan Kabupaten Kutai Barat tahun 2006 hingga tahun 2015.

4) Data Tenaga Kerja Sektor Pertambangan Kabupaten Kutai Barat tahun 2006 hingga tahun 2015.

5) Data IPM Kabupaten Kutai Barat tahun 2006 hingga tahun 2015.

\section{Sumber Data}

Dalam analisis ini menggunakan data sekunder yang diperoleh dari dinas dan instansi terkait di Kabupaten Kutai Barat

\section{Instrumen Penelitian}

Mengingat data yang digunakan dalam penelitian ini adalah data sekunder, maka untuk mengumpulkan data tidak menggunakan instrument kuisioner, tetapi hanya menggunakan ceklist daftar kebutuhan data sekunder yang diperoleh melalui berbagai publikasi, yaitu dari Badan Pusat Statistik (BPS) Kabupaten Kutai Barat dan Provinsi Kalimantan Timur, Kantor Bapeda Kabupaten Kutai Barat, Dinas Pertambangan Kabupaten Kutai Barat serta Dinas lainnya yang terkait.

\section{Teknik Pengumpulan Data}

Teknik pengumpulan data yang digunakan:

a) Pengumpulan data, pengumpulan data dimaksudkan untuk mendapatkan data yang telah tersedia dengan cara mengumpulkan dokumen, surat-surat, buku-buku dan semua sumber data sekunder dari berbagai sumber data.

b) Wawancara, wawancara dimaksudkan untuk mendapatkan data secara langsung melalui wawancara tidak terstruktur kepada pimpinan Dinas dan Badan penyedia data, untuk hal-hal yang sifatnya tidak tertulis (Library Research)

\section{Alat Analisis dan Pengujian Hipotesis}

Metode analisis data dalam penelitian ini menggunakan analisis jalur (path analysis). Analisis jalur merupakan perluasan dari analisis regresi linier berganda, atau analisis jalur adalah penggunaan analisis regresi untuk menaksir hubungan kausalitas antar variabel yang telah ditetapkan sebelumnya berdasarkan teori (Ghozali, 2011: 249).

Pada dasarnya koefisien jalur (path) adalah koefisien regresi yang distandarkan yaitu koefisien regresi yang dihitung dari basis data yang telah di set dalam angka baku atau Z-score (data yang di set dengan nilai rata-rata $=0$ dan standar deviasi $=1$ ). Koefisien jalur yang disatandarkan (standardized path coefficient) ini dipergunakan untuk menjelaskan besarnya pengaruh (bukan memprediksi) variabel bebas (exogen) terhadap variabel lain yang diberlakukan sebagai variabel terikat (endogen).

\section{HASIL DAN PEMBAHASAN}

Dari analisis regresi terhadap model persamaan sub struktur 1 dan model persamaan sub struktur 2, diperoleh hasil pengujian terhadap hipotesis yang telah diajukan, dapat dijelaskan beberapa hal yang berhubungan dengan pengaruh masing- masing variabel eksogen terhadap variabel endogen sebagaimana berikut:

\section{Pengaruh Investasi Pertambangan terhadap PDRB}

Berdasarkan hasil uji -thitung <-ttabel $(-6,171<-2,365)$ atau t hitung > t tabel $(6,171>2,365)$ dan signifikansi $<0,05(0,00<0,05)$, Investasi Pertambangan berpengaruh positif dan signifikan terhadap penerimaan 
PDRB di Kabupaten Kutai Barat. Investasi Pertambangan sangat mempengaruhi penerimaan PDRB di Kabupaten Kutai Barat sekaligus membuktikan bahwa data yang dikumpulkan berhasil membuktikan keterkaitan antara Investasi Pertambangan dan penerimaan PDRB. Hal ini juga terlihat dari komposisi konstribusi sektor Pertambangan sebagai penopang utama pembentukan PDRB Kabupaten Kutai Barat yakni sekitar 53,15\%.

Menurut Wijaya (1990:262), pertumbuhan ekonomi satu wilayah dapat dicerminkan melalui nilai Produk Domestik Regional Bruto (PDRB). Dimana PDRB secara agresif menunjukkan kemampuan daerah tertentu dalam menghasilkan pendapatan atau balas jasa kepada faktor produksi yang ikut berpartisipasi dalam proses produksi di daerah tersebut. PDRB diartikan sebagai total nilai produksi barang dan jasa yang diproduksi di wilayah tertentu dalam kurun waktu tertentu (satu tahun). Hal ini menunjukkan besarnya nilai tambah produksi yang dihasilkan dari berbagai sektor yang melakukan kegiatan usahanya di satu daerah tanpa mementingkan faktor produksi yang dipakai. Sedangkan menurut Elfianti (2011:14), peningkatan PDRB dapat juga diartikan sebagai peningkatan jumlah output yang tentunya dapat berpengaruh terhadap pendapatan per kapita yang kemudian akan mempengaruhi kemampuan masyarakat dalam membayar pungutan, baik itu pajak, retribusi maupun pungutan - pungutan lain yang diterapkan oleh pemerintah daerah. Besarnya kecilnya investasi yang ditanamkan dalam suatu perusahaan tidaklah secara mutlak menjamin terciptanya output dan produktifitas yang tinggi. Menurut Winardi (1998:69), pengertian investasi adalah pertama, pembelian saham-saham, obligasi dan benda-benda tak bergerak yang setelah dilakukan analisa akan menjamin modal yang diletakkan memberikan hasil memuaskan. Faktor-faktor tersebut membedakan investasi dengan spekulasi. Kedua, dalam teori ekonomi maka investasi berarti pembelian alat-alat produksi, termasuk didalamnya benda- benda untuk dijual dengan modal berupa uang. Hal ini sejalan dengan hasil penelitian Abdul Rasyid (2002) bahwa Investasi mempengaruhi PDRB Kaltim dan memiliki pengaruh positif dan nyata terhadap PDRB Kaltim.

\section{Pengaruh Jumlah Tenaga Kerja terhadap PDRB}

Berdasarkan hasil uji t, jumlah Tenaga Kerja mempunyai pengaruh positif dan signifikan terhadap penerimaan PDRB, dengan hasil thitung $>$ ttabel $(-0,260>2,365)$ dan signifikansi $<0,05(0,107>0,05)$. Perubahan jumlah Tenaga Kerja sektor pertambangan memberikan kontribusi yang negative dan tidak signifikan terhadap penerimaan PDRB yaitu kenaikan atau penurunan jumlah Tenaga Kerja akan berdampak pada kenaikan atau penurunan penerimaan PDRB Kabupaten Kutai Barat. Hal ini dimungkinkan karena pada sektor pertambangan batu bara tidak membutuhkan tenaga kerja yang begitu besar dan nampak dalam analisa kelayakan masing-masing perusahaan hanya membutuhkan tenaga kerja yang terbatas karena banyak menggunakan peralatan yang modern sehingga investasi yang diperlukan cukup besar. Data pendukung lainnya bahwa di Kutai Barat, Tenaga kerja produktif tertinggi sebagai faktor produksi pada sektor tradisional yang meliputi : Sektor S (service) yaitu sektor perdagangan, perhubungan, keuangan dan jasa, sektor ini pada tahun 2014 sebesar 50,51 \% dari total pekerja, sektor A (agriculture) terbanyak kedua yakni sebanyak 34,03\% dari total pekerja, sektor modern, yaitu sektor M (Manufacture) yang terdiri atas sektor bangunan, sebanyak $23,36 \%$ dari seluruh pekerja yang ada di Kutai Barat.

\section{Pengaruh Investasi Pertambangan terhadap IPM}

Dari hasil analisis diperoleh bahwa Investasi Pertambangan berpengaruh positif dan signifikan terhadap IPM di Kabupaten Kutai Barat. Semakin tinggi pendapatan seseorang maka akan semakin tinggi pula kemampuan orang untuk memenuhi kebutuhannya. Dalam konsep makro dapat dianalogikan bahwa semakin besar Investasi yang ditanamkan akan semakin meningkatkan jumlah kebutuhan untuk pemenuhan Indeks Pembangunan Manusia, Jadi dengan adanya peningkatan Peningkatan Investasi maka hal ini mengindikasikan akan mengurangi kemampuan untuk meningkatkan Indeks Pembangunan Manusia.

Hal yang sama ditujukkan dari hasil penelitian ini bahwa di Kabupaten Kutai Barat, peningkatan Investasi Pertambangan akan meningkatkan penerimaan daerah Kabupaten Kutai Barat. Dengan kata lain, semakin tinggi Investasi Pertambangan satu daerah, akan meningkatkan Nilai Produksi yang mengarah 
Pengaruh Investasi Pertambangan dan Tenaga Kerja; Yakin Masiku

kepada Peningkatan PDRB namun belum tentu akan meningkatkan pemenuhan Indeks pembangunan Manusia di daerah tersebut. Hal ini yang terjadi dari hasil penelitian ini bahwa peningkatan Investasi sektor pertambangan di Kutai Barat belum mampu meningkatkan kualitas IPM karena tidak berhubungan langsung terhadap sektor penunjang IPM seperti pendidikan dan kesehatan.

\section{Pengaruh Jumlah Tenaga Kerja terhadap IPM}

Berdasarkan hasil -ttabel $\leq$ thitung $\leq$ ttabel $(-2,447<1,545>2,447)$ dan signifikansi $<0,05(0,173$ $>0,05)$, maka H0 diterima. Jadi disimpulkan bahwa Jumlah Tenaga Kerja tidak berpengaruh signifikan terhadap IPM, karena peranan Tenaga Kerja sangat menopang peningkatan PDRB karena merupakan salah satu factor produksi namun pengaruhnya terhadap pertumbuhan Indeks Pembangunan Manusia di Kabupaten Kutai Barat belum signifikan.

Hal ini dimungkinkan mengingat posisi data tenaga kerja sektor pertambangan yang ada sesuai dengan data study kelayakan masing-masing perusahaan bahwa perusahaan pertambangan merupakan perusahaan yang padat investasi/modal (capital intensive) namun bukan padat karya (tenaga kerja) karena walaupun investasi yang dibutuhkan sangat besar namun tidak secara otomatis menggunakan tenaga yang besar pula karena menggunakan peralatan produksi yang tidak terlalu membutuhkan banyak tenaga kerja. Hal lainnya bahwa tenaga kerja di Kutai Barat banyak di support oleh sektor-sektor ekonomi lainnya sehingga ketika dihubungkan dengan Indeks Pembangunan Manusia (IPM) yang merupakan akumulasi dari keseluruhan pencapaian di Kabupaten Kutai Barat memberikan pengaruh positif namun tidak signifikan karena bukan factor dominan tetapi ada factor lain yang lebih mempengaruhi.

\section{Pengaruh PDRB terhadap IPM}

Berdasarkan hasil analisis diperoleh nilai thitung > ttabel $(4,685>2,447)$ dan signifikansi < $0,05(0,003<0,05)$, maka H0 ditolak. Jadi disimpulkan bahwa PDRB berpengaruh signifikan terhadap IPM. Seiring dengan meningkatnya PDRB maka akan diikuti pula peningkatan kualitas Indeks Pembang Manusia (IPM). Hal ini berarti apabila terjadi peningkatan PDRB maka akan meningkatkan IPM

\section{Pengaruh Investasi Pertambangan terhadap IPM melalui PDRB}

Salah satu indikator penting untuk diketahui kondisi ekonomi di suatu wilayah atau kabupaten dalam periode tertentu ditunjukkan oleh data Produk Domestik Regional Bruto (PDRB). PDRB merupakan salah satu ukuran tingkat keberhasilan pembangunan di bidang ekonomi yang memuat gambaran perekonomian regional secara makro. PDRB secara agresif menunjukkan kemampuan suatu daerah dalam menghasilkan pendapatan atau balas jasa kepada faktor-faktor yang ikut berpartisipasi dalam proses produksi di daerah tersebut. Dari hasil Penelitian ini dapat disimpulkan semakin tinggi Investasi Pertambangan maka akan semakin mendorong peningkatan PDRB dan sekaligus dapat meningkatkan kualitas IPM di Kabupaten Kutai Barat. Atau dengan kata lain semakin tinggi tingkat Investasi Pertambangan maka semakin tinggi pula potensi sumber penerimaan daerah tersebut sehingga PDRB semakin meningkat dan akan mempengaruhi peningkatan Indeks Pembangunan Manusia (IPM).

Hal ini sejalan dengan penelitian Misran (2008) Bahwa Pengaruh Investasi secara simultan berpengaruh nyata terhadap IPM Kabupaten Kutai Barat.

\section{Pengaruh Jumlah Tenaga Kerja terhadap IPM melalui PDRB}

Dari hasil dekomposisi koefisien jalur sebagaimana disajikan dalam tabel 5.9 diperoleh koefisien jalur sebesar -0,4165 untuk pengaruh total Jumlah Tenaga Kerja terhadap IPM melalui PDRB .

Dengan meningkatnya penerimaan PDRB yang dipengaruhi oleh pertumbuhan jumlah Tenaga Kerja sektor pertambangan maka belum mempengaruhi secara signifikan Indeks Pembangunan Manusia mengingat dari hasil pengolahan data Tenaga kerja tersebut belum mencapai titik pemenuhan kebutuhan tenaga kerja yang semestinya. Dengan penjelasan tersebut nampak jelas bahwa pertumbuhan penduduk bila ditangani secara serius dan dilengkapi dengan keahlian dan keterampilan akan menambah jumlah Tenaga 
Kerja tepat sesuai kebutuhan yang akan mendorong peningkatan produktifitas yang akan meningkatkan PDRB sekaligus dapat meningkatkan Indeks Pembangunan Manusia kedepan.

\section{SIMPULAN}

Berdasarkan hasil analisis dan pembahasan maka dapat ditarik kesimpulan sebagai berikut:

1. Investasi Pertambangan berpengaruh langsung dan signifikan terhadap PDRB di Kabupaten Kutai Barat. Investasi Pertambangan secara signifikan berpengaruh terhadap PDRB di Kabupaten Kutai Barat, hal ini membuktikan bahwa data yang dikumpulkan dan dianalisis berhasil membuktikan keterkaitan antara Investasi Pertambangan dan PDRB.

2. Jumlah Tenaga kerja tidak berpengaruh secara langsung dan signifikan terhadap PDRB. Berarti peningkatan jumlah Tenaga kerja belum meningkatkan PDRB, namun Peningkatan PDRB Kabupaten Kutai Barat yang tidak stabil disebabkan oleh banyaknya sektor ekonomi lainnya yang ikut berpengaruh terhadap fluktuatif PDRB Kabupaten Kutai Barat.

3. Investasi Pertambangan berpengaruh tidak langsung dan signifikan terhadap IPM Kabupaten Kutai Barat. Peningkatan PDRB per kapita akan meningkatkan penerimaan daerah Kabupaten Kutai Barat. Pendapat ini sejalan dengan Hakim Halim (2000), bahwa Pendapatan Asli Daerah dipengaruhi oleh Produk Domestik Regional Bruto. Hal ini juga akan berimbas kepada peningkatan Indeks Pembangunan Manusia mengingat pemenuhan kualitas IPM akan semakin memungkinkan dengan adanya peningkatan PDRB.

4. Jumlah Tenaga Kerja sektor pertambangan berpengaruh langsung namun tidak signifikan terhadap IPM Kabupaten Kutai Barat, mengingat jumlah tenaga kerja di Kutai Barat banyak disupport oleh sektor ekonomi lainnya karena peranan tenaga kerja yang tinggi akan menopang produktifitas yang sekaligus akan menopang peningkatan kualitas hidup dan pemenuhan kebutuhan hidup sebagimana menjadi indikator perhitungan IPM.

5. PDRB berpengaruh secara langsung dan signifikan terhadap Indeks Pembangunan Manusia di Kabupaten Kutai Barat. Seiring dengan meningkatnya penerimaan PDRB maka akan diikuti pula peningkatan Indeks Pembangunan Manusia.

6. Investasi Pertambangan secara tidak langsung berpengaruh positif namun tidak secara signifikan terhadap Indeks Pembangunan Manusia di Kabupaten Kutai Barat.

7. Tenaga Kerja sektor pertambangan tidak berpengaruh langsung dan signifikan terhadap Indeks Pembangunan Manusia melalui PDRB di Kabupaten Kutai Barat, dengan meningkatnya PDRB yang dipengaruhi oleh pertumbuhan jumlah tenaga kerja belum menjamin peningkatan IPM. Dengan penjelasan tersebut nampak jelas bahwa komposisi tenaga kerja sektor pertambangan belum pada posisi yang ideal mempengaruhi IPM secara tepat hal ini dimungkinkan faktor efisiensi biaya produksi, maraknya pemutusan kerja/PHK, karena bila ditangani tepat dan jumlah yang tepat akan menambah peningkatan kualitas hidup yang diukur dengan Indeks Pembangunan Manusia.

\section{SARAN}

Berdasarkan kesimpulan diatas, maka diajukan saran kepada PemerintahDaerah selaku aparat yang paling bertanggung jawab terhadap pembangunan :

1. Investasi Pertambangan berpengaruh signifikan terhadap penerimaan PDRB maka kepada Pemerintah Kabupaten Kutai Barat supaya dapat menciptakan iklim kondusif bagi investasi dalam upaya meningkatkan perekonomian masyarakat Kabupaten Kutai Barat

2. PDRB Kabupaten Kutai Barat selama ini sebagian besar ditopang oleh Sektor Pertambangan dan Penggalian dimana memanfaatkan sumber daya alam yang tidak terbaharukan yang suatu saat akan habis maka diharapkan kepada Pemerintah Kabupaten Kutai Barat juga mengupakan peningkatan konstribusi sektor-sektor ekonomi lainnya seperti Pertanian, Industri Pengolahan, Pariwisata dan Jasa dan lain-lain agar kondisi ekonomi Kabupaten Kutai Barat kedepan semakin tangguh dan handal dan tidak terpaku dengan sektor pertambangan saja. 
3. Agar Pemerintah Kabupaten Kutai Barat mendorong dan memprioritaskan pembangunan di sektorsektor yang menopang peningkatan kualitas hidup masyarakat dengan peningkatan investasi publik dan swasta terutama yang bersifat pembangunan sumber daya manusia seperti investasi di bidang pendidikan, kesehatan dan sarana prasarana penunjang ekonomi sehingga investasi tidak hanya meningkatkan pertumbuhan ekonomi saja, tetapi juga akan meningkatkan nilai IPM yang tinggi dan merata di seluruh wilayah Kabupaten Kutai Barat, baik yang pendanaannya bersumber dari pemerintah Pusat dan Daerah maupun dari CSR atau community development perusahaan swasta yang berusaha di Kabupaten Kutai Barat.

\section{DAFTAR PUSTAKA}

Anonim, 994, Undang-Undang RINo. 12 TAHUN 1994, tentang Perubahan Atas Undang- Undang Nomor 12 Tahun 1985 tentang Pajak Bumi Dan Bangunan, Jakarta.

Anonim, 2003, Undang-Undang No. 17 Tahun 2003, tentang Keuangan Negara, Jakarta.

Anonim, 2004, Undang-undang Nomor 32 Tahun 2004, tentang Pemerintahan Daerah, Jakarta.

Anonim, 2004, Undang-undang Noor 34 Tahun 2004, tentang Perimbangan Keuangan Pusatdan Daerah, Jakarta

Anonim, 2000,Peraturan Pemerintah RI Nomor 105 Tahun 2000 tentang Pengelolaan dan Pertanggungjawaban Keuangan Daerah.

Arsyad, Licodin, 1999. Pengantar Perencanaan dan Pembangunan Ekonomi Daerah. BPFE, Yogyakarta

Badan Pusat Statistik, 2014, Kutai Barat DalamAnggka 2014

Badan Pusat Statistik, 2015, Kutai Barat DalamAnggka 2015

Badan Pusat Statistik, 2015, Kutai Barat DalamAnggka 2016

Badan Pusat Statistik dan BAPPEDA, 2015, Analisis Tinjauan Perekonomian Kabupaten Kutai Barat 2015.

BAPPEDA, 2013, Produk Domestik Regional Bruto (PDRB) Kabupaten Kutai Barat Menurut Penggunaan 2010-2013

BAPPEDA, 2013, Produk Domestik Regional Bruto (PDRB) Kabupaten Kutai Barat Menurut Lapangan Usaha 2010-2013

BAPPEDA, 2015, Profil Daerah Kabupaten Kutai Barat 2015.

Ahmad Antoni K. Muda, 2003, Kamus Bahasa Ekonomi, Cetakan 1Gitamedia Press, Surabaya.

Achmad Rizal (2010), Analisis Faktor yang Mempengaruhi Pendapatan Asli Daerah Provinsi Kalimantan Timur, Tesis Tidak dipublikasikan. Program Pascasarjana Universitas Mulawarman, Samarinda.

Baswir, Revrisond. 2001.Akuntansi Pemerintahan Indonesia, Yogyakarta.

Bratakusumah dan Solihin (2002), Otonomi Penyelenggaraan Pemerintah Daerah, Gramedia Pustaka Utama, Jakarta

Chalid, Pheni. 2005, "Keuangan Daerah Investasi dan Desentralisasi“. Kemitraan Partnership. Jakarta

Devas, Nick dik, Keuangan Pemerintah Daerah Di Indonesia, Penerbit Universitas Indonesia Press, Jakarta, 1989.

Ghozali, Imam, 2009. Aplikasi Analisis Multivariate Dengan Program SPSS, Edisi Keempat, Penerbit Universitas Diponegoro. 
Ghozali, 2011. Aplikasi Analisis Multivariate Dengan Program SPSS. Semarang: Badan Penerbit Universitas Diponegoro

Harahap, Fenty R., 2002. Pengaruh Modal dan Tenaga Kerja dan Tenaga Kerja terhadap Produksi Batu Bara di Kabupaten Kutai Kertanegara. Tesis Program Pascasarjana Magister Sains Universitas Hasanuddin, Makassar.

Iberahim, 2007, Pengaruh Produk Domestik Regional Bruto (PDRB) dan Penduduk Terhadap Penerimaan Pajak dan Non Pajak di Kabupaten Kutai Barat. Tesis, Tidak dipublikasikan. Program Pascasarjana Universitas Mulawarman, Samarinda.

Insukindro, Mardiasmo., Wahyu Widayat, Wihana Kirana Jaya, Purwanto, Abdul Halim, John Suprihanto, Budi Purnomo. (1994). Peranan Pengelolaan Keuangan Daerah dalam usaha peningkatan PAD. Laporan hasil penelitian $K K D$. Yogyakarta: FE UGM

Irawan, M. Suparmoko, 1995, Ekonomika Pembangunan, Edisi 5 Cetakan ke empat, Yogyakarta, Penerbit BPFE.

Jeddawi, Murtir., 2005. Memacu Investasi di Era Otonomi Daerah; Kajian Beberapa Perda Tentang Penanaman Modal. UII Press, Yogyakarta.

Kaho J. Riwu. 2007. Analisis Hubungan Pemerintahan Pusat dan Daerah, Rineka Cipta.

Keynes, Muana., 2001. Teori Umum Mengenai Kesempatan Kerja, Bunga dan Uang. Gadjah Mada University Press, Yogyakarta.

Nanga, Muana., 2001. Makroekonomi; Teori, Masalah dan Kebijakan. Edisi Perdana. Radjawali Persada, Jakarta.

Makmur 2010, Faktor - factor yang Mempengaruhi Penerimaan PBB-Pajak Bumi dan Bangunan di Kabupaten Kutai Barat. Jurnal Eksis.

Mamesa, DJ. (2004). Sistem Administrasi Keuangan Daerah, Jakarta, Gramedia Pustaka Utama

Mangkoesoebroto, Guritno, 1993, Ekonomi Publik, Edisi-III, BPFE, Yogyakarta

Musgrave, Richard A. 1993 Keuangan negara dalam teori dan praktek, Erlangga, Jakarta.

Prijono, Tjiptoherjanto., 1982. Sumber Daya Manusia, Kesempatan Kerja dan Pembangunan Ekonomi, Fakultas Ekonomi Universitas Indonesia, Jakarta.

Priyatno, Dwi, 2008. Mandiri Belajar SPSS untuk Analisis Data dan Uji Statistik, Edisi Pertama, Mediakom, Jakarta.

Riduwan, Engkos A. Kuncoro, 2010, Cara Menggunakan dan Menggunakan Path Analysis (Analisis Jalur), ALFABETA Bandung. Rahman, Herlina. 2005. Pendapatan Asli Daerah.

Rasyid, Abdul., 2002. Pengaruh Investasi dan Tenaga Kerja terhadap PDRB Kaltim. Tesis Pascasarjana Magister Sains Universitas Hasanuddin Makassar.

Saragih, Juli Panglima.2003. Desentralisasi Fiskal dan Keuangan Daerah dalam Otonomi. Penerbit Ghalia Indonesia. Jakarta.

Sarwoko, 2005. Dasar - Dasar Ekonometrika. Penerbit Andi. Yogyakarta

Siti Yusnani, 2014, Faktor - factor yang mempengaruhi Pendapatan Asli Daerah (PAD) dan Indeks Pembangunan Manusia (IPM) Provinsi Kalimantan Timur, Tesis, Tidak dipublikasikan. Program Pascasarjana Universitas Mulawarman, Samarinda.

Sugiyono, 2005, Metode Penelitian Kualitatif, Bandung: Alfabeta 
Sukirno,Sadono.(2002), Makro Ekonomi Teori Pengantar. Jakarta: PT Raja Grafindo Persada,

Wijaya, HAW. (2002) Otonomi Daerah dan Daerah Otonom Jakarta : PT Raja Grafindo Persada .

Wijaya, HAW. (2005) “ Penyelenggaraan Otonomi Di Indonesia” Jakarta : PT Raja Grafindo Persada. 